\title{
Acute Toxicity Test of Ethanolic Extract of Dayak Onion Leaves (Eleutherine americana Merr.) Toward Wistar Female Rats Using OECD 425 Method
}

\author{
Sri Wahdaningsih, Eka Kartika Untari and Robiyanto
}

Department of Pharmacy, Medical Faculty, Tanjungpura University, Pontianak, 78124, Indonesia

(Received: January 08, 2019; Accepted: May 30, 2019; Published (Web): October 5, 2019)

\begin{abstract}
Pre-clinically, the potential of Eleutherine americana Merr. as antioxidant has been studied, but it's safety level of its safety has not been widely known. Safety level of ethanolic extract of E. americana Merr leaves (EEEaL) can be detected by acute toxicity test using OECD 425. The aim of this study was to investigate the acute toxicity of EEEaL as the guideline of its safe dose for therapy. This test was performed through OECD 425 (Up and Down Procedure) method with two doses (2000 and $5000 \mathrm{mg} / \mathrm{kgbw}$ ) of EEEaL administration orally which observed for two weeks toward Wistar rats. The results of the test dose showed no toxic symptoms and they did not cause death in the test animals. Single dosage up to $5000 \mathrm{mg} / \mathrm{kgbw}$ also did not show any symptoms of toxicity, and did not cause weight loss until the $14^{\text {th }}$ day of test. The $\mathrm{LD}_{50}$ value of EEEaL is more than $5000 \mathrm{mg} / \mathrm{kgbw}$, suggesting that the plants is practically non toxic according to Loomis classification. Phytochemical screening showed that EEEaL contains compounds such as alkaloids, flavonoids, triterpenoids, steroids, and saponins.
\end{abstract}

Key words: Eleutherine americana, leaves, acute toxicity, OECD 425.

\section{INTRODUCTION}

Indonesia is world's third the most active smoker after China and India while the smoker number increases annually not only in Indonesia, but also all over the world. ${ }^{1}$ Long term smoking affects closly related to prevalence of diseases such as chronic obstructive pulmonary disease (COPD), lungs cancer, atherosclerosis which caused adverse effect. ${ }^{2}$ Each cigarette comprises a number of dangerous chemicals such as nicotine, carbon monoxide, tar, etc. One time smoking produces $10^{14-16}$ oxidant molecule within the smoke such as superoxide, hydrogen peroxide, hydroxyl, and peroxyl free radical. $^{3}$ Oxidant molecules can lead to oxidative stress characterized by increasing amounts of oxidant radicals, the total of leukocytes and blood neutrophils. ${ }^{4}$ Free radical molecule from the cigarette smoke catalysts the

Correspondence to: Sri Wahdaningsih

Email: wahdanieanie@gmail.com

Dhaka Univ. J. Pharm. Sci. 18(2): 171-177, 2019 (December) DOI: https://doi.org/10.3329/dujps.v18i2.43259 peroxidation of double unsaturated fatty acid of cell membrane which strengthened oxidative stress level during smoking activity. ${ }^{5,6}$ The longer somebody smokes the higher MDA level on their bodies. ${ }^{7}$

Dayak onion leaves plant or Mekah onion leaves also has antioxidant activity potential. According to the research of Andriyani (2014), it is known that Dayak onion extract has potential as an antioxidant against cigarette smoke exposure by decreasing MDA level. Another study also suggested that ethanolic extract of Dayak onion leaves may decrease the degree of lung damage caused by the exposure to cigarette smoke. ${ }^{8}$ The acute toxicity test is a safety test in a short time to detect any toxic effects of a given test substance in a single or recurrent dose within 24 hours. ${ }^{9}$ This test aims to investigate the safety of ethanolic extract of Dayak onion leaves administration orally toward test animals by observing several test parameters such as $\mathrm{LD}_{50}$, body weight change, organ index, and behavior. Acute toxicity test results will give an insight of the acute 
reaction of living things when administered certain medicinal substance. ${ }^{10}$

\section{MATERIAL AND METHODS}

Sample collection. Dayak onion leaves were collected from Kubu Raya regency and then identified at the Laboratory of Biology in Faculty of Mathematics and Sciences UNTAN. The result showed that the official name of this species is Eleutherine americana Merr. with local name Bawang Dayak.

Extraction. The method of extraction that was conducted was maceration. One $\mathrm{kg}$ dried leaves of dayak onion was macerated with 1.5 litres of ethanol (70\%) for 72 hours (3 days in a row). After every 24 hours, ethanol was replaced with the new ethanol solvent and macerate was stirred regularly. The next step of this macerate was to filter and evaporate the solvent using rotary evaporator.

Extraction standard. Specific parameters used in this research include organoleptic assay, soluble compound content, water soluble content, total flavonoid determination.

Non-specific parameters used in this research are moisture content, ash content parameter, bacterial total and mold total assay, Lead $(\mathrm{Pb})$ limit determination.

Acute toxicity test using OECD 425 method. Acute toxicity test was performed using OECD 425 according to Acute Oral Toxicity-Acute Toxic Class Method. ${ }^{9}$ The experimental animal in this research is female Wistar rats at the age of 6-8 weeks, with minimal body weight about 150 grams. $\mathrm{LD}_{50}$ value was obtained through counting the death and alive rats while performing each test for maximum 48 hours after treatment. The stages of oral acute toxicity test were as follow. The rats were fasted overnight and then the body weight was measured. In the first test, the first rat was given a dose limit of $2000 \mathrm{mg} / \mathrm{kgbw}$ of ethanolic extract of Dayak onion leaves and let it rest for 48 hours. If the first animal lives, then 4 test animals were given the same dose. If 3 or more die then the dose of the main test was processed. If 3 or more live the observation was continued till 14 days. The treatment was continued to the limit test dose 5000, if the number of animals that live more was than 3 in the test of the test dose limit of $2000 \mathrm{mg} / \mathrm{kgbw}$. In the test limit test dose 5000 , if the number of animals live is more than 3 then the value of $\mathrm{LD}_{50}>5000 \mathrm{mg} / \mathrm{kgbw}$. If the number of live animals is less than 3 then it is continued to the main test test.

Acute toxicity observation parameters of this study include $\mathrm{LD}_{50}$ values, observation of toxic symptoms, changes in body weight. Toxic symptoms were analyzed qualitatively during testing based on the criteria set by OECD 425 including platform, straub, piloerection, ptiosis, corneal reflex, pineal reflex, lacrimation, catalepsy, body posture, hanging, retablismen, flexion, hafner, mortality, grooming, defecation, urination, breathing, salivation, vocalization, tremors, seizures and writhing. Body weight changes was quantitatively analyzed from weighing on the first day of test preparation until the $14^{\text {th }}$ day of observation.

The first observation of toxic symptoms was performed individually at $0,0.5,1$ to 2 hours after administration. Then the observations were performed again at the $24^{\text {th }}$ hour and $14^{\text {th }}$ day unless the animals die . Finally observation was stopped.

$\mathbf{L D}_{50}$ assessment. $\mathrm{LD}_{50}$ value was assessed statistically including maximum likelihood method. All the doses and animal test responses were used for input to AOT425StatPgm software to obtain the value $\mathrm{LD}_{50}$ estimation.

\section{RESULTS AND DISCUSSION}

Extraction. Maceration method provided 35.7 gram of extract with yield value of $17.85 \%$.

\section{Extract standardization}

Specific parameter. Organoleptic parameters of the extract were determined with senses to give the first impression of extract objectively such as form, colour, taste, and smell. The result showed that ethanolic extract of Dayak onion leaves was condense, blackish brown, unique smell, and bitter taste. 
The assessment of soluble compound content within certain solvent (water/ethanol) aims to give preliminary depiction of compound number that can be extracted within the solvent (water/ethanol) ${ }^{11}$. The required amount of soluble compound within certain solvent (water/ethanol) is $=18$ for water solvent and $=12.5$ for ethanol solvent ${ }^{12}$. The test result of water soluble compound of Dayak onion leaves as much as $20.2 \%(\mathrm{w} / \mathrm{w})$.

Flavonoid total assay is performed through spectrophotometry UV-Vis using quercetin comparator. Flavonoid determination principle is based on colorimetric reaction of $\mathrm{AlCl}_{3}$ with keto group on $\mathrm{C}-4$ atom as well as hydroxy group on $\mathrm{C}-3$ or $\mathrm{C}-4$ atom which neighbour of flavone and flavonol which could be analyzed in visible area. Calibration curve making is using quercetin as comparator, which quercetin is flavonoid in flavonol class that has keto group on C-4 atom and has hydroxy group on C3 and C-5 atom. They neighbour to flavone and flavonol. Absorbance of standard liquid is measured on $510 \mathrm{~nm}$ wave length using spectrophotometry UvVis. Standard curve is obtained from the relation between quercetin concentration $(\mathrm{mg} / \mathrm{L})$ and absorbance $^{13}$. The result shows that total flavonoid of quercetin equivalent on ethanolic extract of Dayak onion leaves as much as $8.08 \%(\mathrm{~b} / \mathrm{b})$. Extract specific parameter test result can be seen on table 1 .

Table 1. Test Result of EEEaL Specific Standard Parameter

\begin{tabular}{lll}
\hline No & Parameter & Result \\
\hline 1 & Organoleptic & Colour : blackish brown \\
& & Form : condense \\
& & $\begin{array}{l}\text { Taste }: \text { bitter } \\
\text { Smell }: \text { unique }\end{array}$ \\
& & $8.08 \% \mathrm{~b} / \mathrm{b}$ \\
2 & Total Equivalent Flavonoid & \\
& Content & $(+)$ flavonoid \\
3 & Active Compound Assay & $20.2 \%(w / w)$ \\
4 & Water soluble compound & \\
& content &
\end{tabular}

Active compound assay using KLT method which the compound used to standardization of Dayak onion leaves ethanolic extract is quercetin. Quercetin compound identification in Dayak onion leaves ethanolic extract using KLT method with specific reactor (vanillin $\mathrm{H}_{2} \mathrm{SO}_{4}$ ). Obtained result respectively show that greenish brown and brick red. Furthermore, KLT result is compared to quercetin compound (comparator compound). KLT result can be seen on Figure 1.

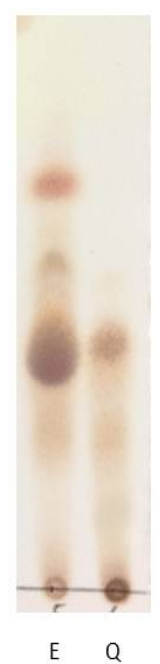

Figure 1. KLT Profile of ethanolic extract of Dayak onion leaves (E) and quersetin $(\mathrm{Q})$ after sprayed by sulphate vanilin for spot apparent flavonoid c luster

Non-specific parameters. Standardization and non-specific aspect are led to permitted maximum limit of dangerous material contain in the extract. Test result of non-specific parameters can be seen on Table 2.

Much amount of water content of extract is risky for it easily decay and fungus growing ${ }^{14}$. In this research, obtained water content of extract as much as $19.55 \%$. Obtained extract is condensed extract type because according to the literature, water content range that required as condensed extract type approximately 5-30\%.

Ash content is parameter that shows of minerals content within the extract. On the ash content assay, all the organic compound will be oxidised into their elements, while the minerals will be turned into their oxide form. Obtained ash content of Dayak onion leaves ethanolic extract as much as $11.83 \%(\mathrm{w} / \mathrm{w})$. Total ash content within Dayak onion extract indicates that gained extract through maceration process contents a lot of minerals. 
Lead content assay within extract is useful to ensure that the extract does not contain lead that surpass the permissioned limit due to its toxic character for human. Research result shows that lead content on ethanolic extract of Dayak onion leaves that assessed through atomic absorption spectrometry is $<0.02 \mathrm{mg} / \mathrm{kgbw}$. Therefore ethanolic extract of Dayak onion leaves is qualified natural medicine standardization parameter. Maximum limit of lead $(\mathrm{Pb})$ contaminant according to Dirjen POM No $03725 / \mathrm{B} / \mathrm{SK} / \mathrm{VII} / 89$ decree is $10 \mathrm{mg} / \mathrm{kg}{ }^{15}$

Bacterial contaminant test include as one of the tests of extract purity requirement. This test comprises determination of microorganism number which permitted and aiming to show that there is no certain bacteria within the extract. Indonesia National Standard (SNI) 19-2897-1992 which designated by the government states that microbes content on processed food product, $<10^{6} \mathrm{CFU} / \mathrm{gram}$ for bacterial class, and $<10^{4} \mathrm{CFU} /$ gram for mold/yeast class. Bacterial contaminant number data of Dayak onion leaves extract as much as $3,5 \times 10^{6} \mathrm{CFU} / \mathrm{gram}$. This number is quite high from required limit number, which is $<10^{6} \mathrm{CFU} / \mathrm{ml}$. While total plate number assessing of extract's mold as much as 1510 $\mathrm{CFU} / \mathrm{g}$, considered as over the maximum limit mold contaminant, which is $<10^{4} \mathrm{CFU} / \mathrm{ml}$. This contamination could happen during sample process until it become extract.

Acute toxicity test. Acute oral toxicity test is one of the pre-clinic test that aims to see toxic effect

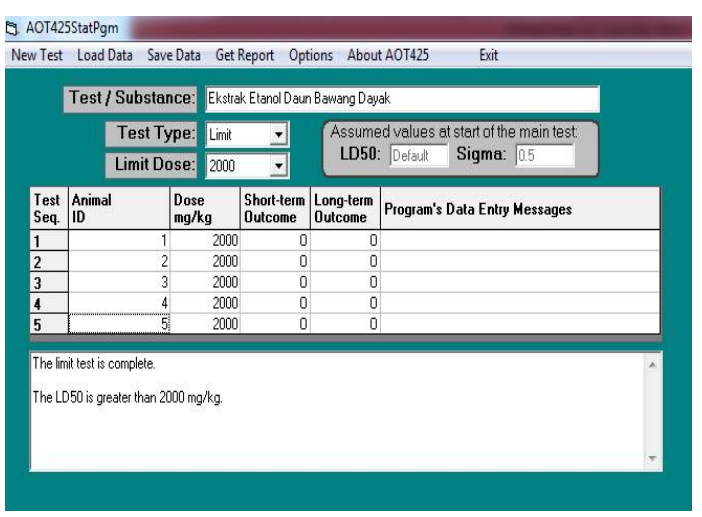

Figure 2. Limit Test Result with Doses 2000 mg/kg bw occured in short period, through single administration each oral or through repeated doses on 24 hours interval. ${ }^{9}$ Animal tests death data states with Lethal Doses $50\left(\mathrm{LD}_{50}\right)$ which is the parameter on acute toxicity test. ${ }^{10} \mathrm{LD}_{50}$ assay is the first step to know the material safety that will be used by humans through assessing the number of doses that can cause 50\% death chance on test animal after single doses administration.

Initial test to discover whether a test material has toxicity at a certain dose is done through the Up and Down Procedure (UDP) method. The UDP method is used in acute toxicity test because it is reliable and efficient in assessing $\mathrm{LD}_{50}$ values. This method can accurately estimate hazard classification and minimize test animals. The dosage used in this study is the limit test according to OECD 425 guidelines. There are two limit tests, they are $2000 \mathrm{mg} / \mathrm{kgbw}$ and $5000 \mathrm{mg} / \mathrm{kgbw}$. Acute toxicity test of ethanolic extract of Dayak onion leaves with doses 2000 $\mathrm{mg} / \mathrm{KgBw}$ limit test aims to discover whether the ethanolic extract of Dayak onion leaves has $\mathrm{LD}_{50}$ over or under $2000 \mathrm{mg} / \mathrm{kgBw}$, while doses 5000 $\mathrm{mg} / \mathrm{kgBB}$ limit test aims to discover whether the ethanolic extract of Dayak onion leaves has $\mathrm{LD}_{50}$ over or under $5000 \mathrm{mg} / \mathrm{kgBB}$. $\mathrm{LD}_{50}$ value is obtained through data processing with AOT425 StatPgm software. Limit test results using doses 2000 $\mathrm{mg} / \mathrm{kgbw}$ and doses $5000 \mathrm{mg} / \mathrm{kgbw}$ are shown on Figure 2 and 3.

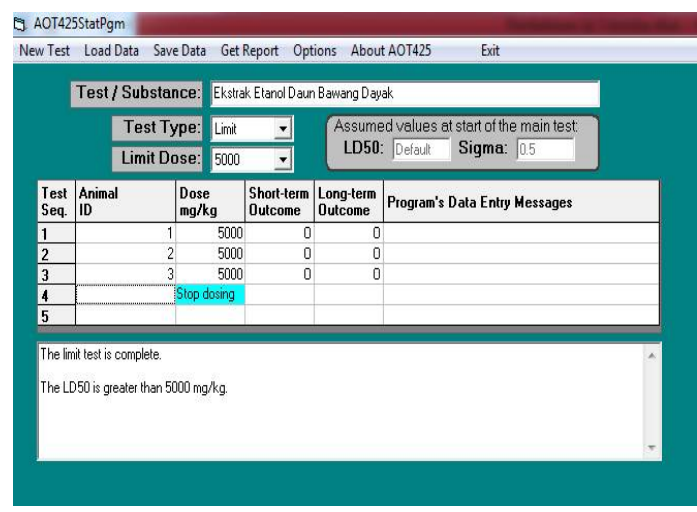

Figure 3. Limit Test Result with Doses $5000 \mathrm{mg} / \mathrm{kg}$ bw 
Table 2. Test Result of EEEaL Non-specific Standard.

\begin{tabular}{lll}
\hline No & Parameter & Result \\
\hline 1 & Water content & $19.55 \%$ \\
2 & Ash content & $11.83 \% \mathrm{~b} / \mathrm{b}$ \\
3 & Heavy metal contaminant & \\
& $-\quad$ Lead & $<0.02 \mathrm{mg} / \mathrm{Kg}$ \\
& $-\quad$ Bacterial total assay & $3,5 \times 10^{6} \mathrm{CFU} /$ gram \\
& $-\quad$ Mold total assay & $1510 \mathrm{CFU} /$ gram \\
\hline
\end{tabular}

Based on the test it can be concluded that the $\mathrm{LD}_{50}$ value of ethanolic extract of Dayak onion leaves is more than $5000 \mathrm{mg} / \mathrm{kgbw}$.

Toxicity signs are observed through behaviour test starts from $0,0.5,1$ and $24 \mathrm{hr}$. This observation tends to see the activity and normal condition of animal tests before and after doses administration.
The observed behaviour test including platform, straub, piloerection, ptosis, corneal reflex, pineal reflex, lacrimation, catalepsy, gesture, hanging, retablismen, flexion, hafner, mortality, grooming, defecation, urination, respiration, salivary, vocalization, tremor, cramping, and writhing. If there any behaviour changing on animal tests after preparation administration, therefore it could be predicted that the pharmacology effect upon the extract apparent. Observation result of behaviour test on doses $2000 \mathrm{mg} / \mathrm{kgbw}$ limit test is shown on Table 3 and 4. In general, behavior test toward rats at the 2000 and $5000 \mathrm{mg} / \mathrm{kgbw}$ limit test show normal results.

Table 3. Test Result of Rats Behaviour on Doses $2000 \mathrm{mg} / \mathrm{kgbw}$

\begin{tabular}{|c|c|c|c|c|c|c|c|c|c|c|c|c|c|c|c|c|c|c|c|c|c|c|c|c|c|c|}
\hline \multirow{2}{*}{\multicolumn{2}{|c|}{ Observed Effect }} & \multicolumn{5}{|c|}{ Rat 1} & \multicolumn{5}{|c|}{ Rat 2} & \multicolumn{5}{|c|}{ Rat 3} & \multicolumn{5}{|c|}{ Rat 4} & \multicolumn{5}{|c|}{ Rat 5} \\
\hline & & 0 & $1 / 2$ & 1 & 2 & 24 & 0 & $1 / 2$ & 1 & 2 & 24 & 0 & $1 / 2$ & 1 & 2 & 24 & 0 & $1 / 2$ & 1 & 2 & 24 & 0 & $1 / 2$ & 1 & 2 & 24 \\
\hline Platform & & 6 & 4 & 1 & 1 & 2 & 8 & 5 & 2 & 3 & 2 & 1 & 8 & 4 & 4 & 5 & - & - & - & - & 6 & 4 & 3 & 3 & 6 & 5 \\
\hline Motoric & Up & - & - & - & - & - & - & - & - & - & - & - & - & - & - & - & - & - & - & - & - & - & - & - & - & - \\
\hline \multirow[t]{3}{*}{ activity } & $\begin{array}{l}\text { Nor- } \\
\text { mal }\end{array}$ & - & - & - & - & - & - & - & - & - & - & - & - & - & - & - & - & - & - & - & - & - & - & - & - & - \\
\hline & Down & - & - & - & - & - & - & - & - & - & - & - & - & - & - & - & - & - & - & - & - & - & - & - & - & - \\
\hline & Quiet & - & - & - & - & - & - & - & - & - & - & - & - & - & - & - & - & - & - & - & - & - & - & - & - & - \\
\hline \multicolumn{2}{|l|}{ Straub } & - & - & - & - & - & - & - & - & - & - & - & - & - & - & - & - & - & - & - & - & - & - & - & - & - \\
\hline \multicolumn{2}{|c|}{ Piloerection } & - & - & - & - & - & - & - & - & - & - & - & - & - & - & - & - & - & - & - & - & - & - & - & - & - \\
\hline \multicolumn{2}{|l|}{ Ptosis } & - & - & - & - & - & - & - & - & - & - & - & - & - & - & - & - & - & - & - & - & - & - & - & - & - \\
\hline \multicolumn{2}{|c|}{ Pinela reflex } & - & - & - & - & - & - & - & - & - & - & - & - & - & - & - & - & - & - & - & - & - & - & - & - & - \\
\hline \multicolumn{2}{|c|}{ Cornea reflex } & - & - & - & - & - & - & - & - & - & - & - & - & - & - & - & - & - & - & - & - & - & - & - & - & - \\
\hline \multicolumn{2}{|c|}{ Lacrimation } & - & - & - & - & - & - & - & - & - & - & - & - & - & - & - & - & - & - & - & - & - & - & - & - & - \\
\hline \multicolumn{2}{|c|}{ Catalepsy } & - & - & - & - & - & - & - & - & - & - & - & - & - & - & - & - & - & - & - & - & - & - & - & - & - \\
\hline \multirow[t]{2}{*}{ Gesture } & Normal & - & - & - & - & - & - & - & - & - & - & - & - & - & - & - & - & - & - & - & - & - & - & - & - & - \\
\hline & $\begin{array}{l}\text { Abnor- } \\
\text { mal }\end{array}$ & - & - & - & - & - & - & - & - & - & - & - & - & - & - & - & - & - & - & - & - & - & - & - & - & - \\
\hline \multicolumn{2}{|l|}{ Hanging } & - & - & - & - & - & - & - & - & - & - & - & - & - & - & - & - & - & - & - & - & - & - & - & - & - \\
\hline \multicolumn{2}{|c|}{ Retablismen } & - & - & - & - & - & - & - & - & - & - & - & - & - & - & - & - & - & - & - & - & - & - & - & - & - \\
\hline \multicolumn{2}{|l|}{ Flexion } & - & - & - & - & - & - & - & - & - & - & - & - & - & - & - & - & - & - & - & - & - & - & - & - & - \\
\hline \multicolumn{2}{|l|}{ Hafner } & - & - & - & - & - & - & - & - & - & - & - & - & - & - & - & - & - & - & - & - & - & - & - & - & - \\
\hline \multicolumn{2}{|l|}{ Mortality } & - & - & - & - & - & - & - & - & - & - & - & - & - & - & - & - & - & - & - & - & - & - & - & - & - \\
\hline Grooming & & - & - & - & - & - & 1 & - & - & - & - & - & - & - & - & - & - & 2 & 3 & 4 & - & - & 2 & 5 & - & - \\
\hline Defecation & & - & - & - & - & - & - & - & - & - & - & - & - & - & - & - & - & - & - & - & - & - & - & - & - & - \\
\hline Urination & & - & - & 1 & - & - & 2 & - & - & 1 & - & 1 & - & - & - & - & 2 & 2 & 1 & 1 & - & - & - & - & - & - \\
\hline Respira- & Fast & - & - & - & - & - & - & - & - & - & - & - & - & - & - & - & - & - & - & - & - & - & - & - & - & - \\
\hline tion & Norma & - & - & - & - & - & - & - & - & - & - & - & - & - & - & - & - & - & - & - & - & - & - & - & - & - \\
\hline & $\begin{array}{l}\text { Sterto- } \\
\text { rous }\end{array}$ & - & - & - & - & - & - & - & - & - & - & - & - & - & - & - & - & - & - & - & - & - & - & - & - & - \\
\hline Salivary & & - & - & - & - & - & - & - & - & - & - & - & - & - & - & - & - & - & - & - & - & - & - & - & - & - \\
\hline Vocalizatic & & - & - & - & - & - & - & - & - & - & - & - & - & - & - & - & - & - & - & - & - & - & - & - & - & - \\
\hline Tremor & & - & - & - & - & - & - & - & - & - & - & - & - & - & - & - & - & - & - & - & - & - & - & - & - & - \\
\hline Cramping & & - & - & - & - & - & - & - & - & - & - & - & - & - & - & - & - & - & - & - & - & - & - & - & - & - \\
\hline Writhing & & - & - & - & - & - & - & - & - & - & - & - & - & - & - & - & - & - & - & - & - & - & - & - & - & - \\
\hline
\end{tabular}


Table 4. Test Result of Rats Behaviour on Doses $5000 \mathrm{mg} / \mathrm{kgbw}$

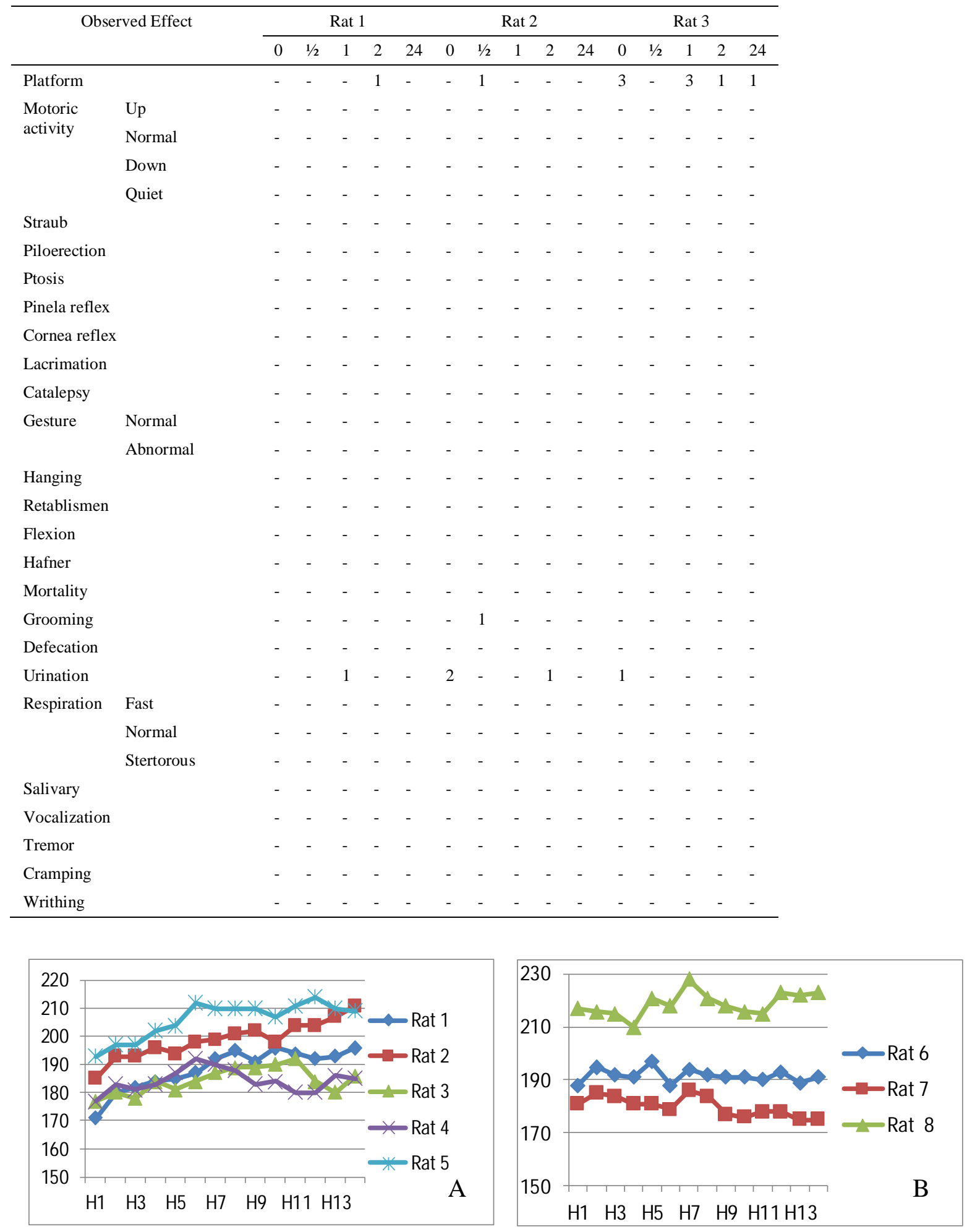

Figure 4. Body Weight Changing Charts on Doses $2000 \mathrm{mg} / \mathrm{kg}$ bw (A) and Body Weight Changing Charts on Doses $5000 \mathrm{mg} / \mathrm{kg}$ bw (B) 
Body weight changing is assessed through rats weighing on the first day until the fourteenth day after the administration of single doses orally. Rats' body weight changing data is presented in chart to observe the test agent effect on body weight condition. Body weight observation performed for 14 days shows that ethanolic extract of Dayak onion leaves administered to the rats on doses 2000 $\mathrm{mg} / \mathrm{kgbw}$ lead to some rats have gained weight and some rats haven't. In rats given ethanolic extract of Dayak leaves with dose as much as $5000 \mathrm{mg} / \mathrm{kgw}$ also occured the same thing. Thus it is proven that the ethanolic extract of Dayak onion leaves at doses of 2000 and $5000 \mathrm{mg} / \mathrm{kgBW}$ generally do not cause weight loss. The results of weight observation data of rats which given doses of 2000 and $5000 \mathrm{mg} / \mathrm{kgBW}$ are shown in Figure 4.

\section{CONCLUSION}

$\mathrm{LD}_{50}$ value of ethanolic extract of Dayak onion leaves found to be more than $5000 \mathrm{mg} / \mathrm{kgBW}$. According to Loomis classification, lethal doses of ethanolic extract of Dayak onion leaves considers as practically non-toxic category. The high $\mathrm{LD}_{50}$ value proves that ethanolic extract of Dayak onion leaves could be the safe therapy agent.

\section{REFERENCES}

1. World Health Organization. 2013. Retrieved from WHO website: http://www.who.int/tobacco/surveillance/policy/ country_profile/idn.pdf

2. Ministry of Health Republic of Indonesia. 2013. Downloaded file:http://www.litbang.depkes.go.id/sites/downloads/ rkd 2013/laporan_riskesdas2013.pdf

3. Yanbaeva, D.G., Dentener, M.A., Creutzberg, E.C., Wesseling, G. and Wouters, E.F. 2007. Systemic effect of smoking. Chest 131, 1557-1566.
4. Koseoglu, M., Isleten, F., Atay, A and Kaplan, Y.C. 2010. Effects of acute and subacute garlic supplement administration on serum total antioxidant capacity and lipid parameters in healthy volunteers. Phytotherapy 24, 374-378.

5. Sela, S., Shurtz-Swirski, R., Awad, J., Shapiro, G., Nasser, L. and Shasha, S.M. 2004. The involvement of peripheral polymorphonuclear leukocytes in the oxidative stress and inflammation among cigarette smokers. Isr. Med. Assoc. J. 4, 1015-1019.

6. Rumley, A.G., Woodward, M. and Rumley A. 2004. Plasma lipid peroxides: factors and prevalent cardiovascular disease. QJM-Int. J. Med. 97, 809-816.

7. Yueniwati, Y. and Ali, M. 2004. Kretek cigarette smoke exposure effect toward fat peroxidase and hepar superoxide dismutase of Wistar Rats. Jurnal Kedokteran YARSI 12, 8592.

8. Al Idrus, H.R., Iswahyudi, I. and Wahdaningsih, S. 2014. Antioxidant activity test of ethanolic extract of mekah onion leaves (Eleutherine Americana Merr.) toward lungs histopathology overview of male wistar rats (Rattus Norvegicus) Post-Exposure of Cigarette Smoke. Journal Fitofarmaka Indonesia 1, 51-60.

9. WHO Publications. 2004. Acute Oral Toxicity-Acute Toxic Class Method. Geneva

10. Dipasquale, L.C. and Hayes, A.W. 2001. Acute toxicity and eye irritancy. Within Wallace Hayes, Taylor \& Francis, editor. Principles and Methods of Toxicology 4th Ed. Philadelphia: Lippincot Williams and Wilkins, pp. 853-75.

11. Ministry of Health Republic of Indonesia. 2000. Universal Standard Parameters of Medicinal Plant. Jakarta: pp. 5, 9-12.

12. Ministry of Health Republic of Indonesia. 1989. Indonesia Medical Material. 5th ed. Jakarta.

13. Azizah, D.N., Endang, K. and Fahrauk, F. 2014. Flavonoid Level Assay with $\mathrm{AlCl}_{3}$ method on methanolic extract of Cacao (Theobroma cacao L.). Kartika J. Ilm. Far. 2, 45-49.

14. Suhendi, A., Nurcahyanti, M. and Sutrisna, E.M. 2011. Antihyperuricemia activity of water extract of black seed (Coleus ambonicus Lou in balb-c mice and its tandardization. Majalah Farmasi Indonesia. 22, 77-84.

15. Arifin, H., Anggraini, N., Handayani, D. and Rasyid, R. 2006. Ethanolic extract of Eugenia Cumini Merr. leaves standardization. J. Sains Tech. PharmFor. 11, 88-93. 